\title{
PRESERVATIVE TREATMENT OF JAK (Artocarpus heterophyllus) SAPWOOD USING CCA \& BORON PRESERVATIVES
}

\author{
G. M. K. Perera1 \& Hiran S Amarasekera² \\ 'Central Erivironment Authority \\ 2Department of Forestry and Environmental Science, \\ University of Sri Jayewardenepura
}

In Sri Lanka Jak timber is listed as a special class timber. Jak timber has high demand for construction and furniture. Jak heartwood is highly durable. However, sapwood is susceptible to borer attack. This study was conducted to determine the suitable and practical treatment method for Jak sapwood to improve its durability. Different aged 10 trees of Jak (Artocarpus heterophyllus) were selected for the study. Sapwood samples and heartwood control samples were extracted from each tree.

Jak sapwood was treated by three methods: Boron (Cold) diffusion and Boron (Hot \& Cold) open tank method using 25\% boron solution and Pressure Impregnation Full-cell process using $2.8 \%$ CCA (Copper Chrome Arsenate) solution. The treatability of different aged trees was evaluated by measuring the preservative retention and depth of penetration. Effectiveness of the treatment was evaluated by percentage weight loss in field exposure test.

According to the results, retention in CCA pressure treated samples was higher compared with boron diffusion methods. Boron (Hot \& Cold) open tank method gave higher retention compared with boron (cold) method. Spot test showed full depth of penetration (100\%) in both boron treatments and $46 \%$ penetration in CCA pressure process.

In field exposure test, the highest weight loss was recorded in boron (Hot \& Cold) treated samples and second weight loss was recorded in boron (Cold) treated samples. There was no significant difference in the weight loss between two boron treatment methods. Weight loss of the CCA pressure treated sampies was very small. Although full depth of penetration was not achieved with CCA pessure impregnation, it was found more effective for the preservation of Jak sapwood.

Based on the results, it is clear that Jak sapwood can be fully treated with boron diffusion methods and effectively treated with CCA pressure impregnation method. Diffusion methods using boron solution is recommended for the interior joinery and CCA pressure impregnation is recommended to use Jak sapwood in exterior construction activities.

However, sapwood of Jak showed other undesirable characters in terms of utilization: compared with heartwood, density of sapwcod was low, and shrinkage was higher.

Proceedings of the Eighth Annual Forestry ard Environment Symposium 2002 of the Department of Forestry and Environmental Science, l/niversity of Sri Jayewardenepura, Sri Lanka 